\title{
Design and Material Selection of Screw Feeder of Injection Molding Machine
}

\author{
Nimish Joshi, Prajakta Hambir, Pranav Karande, Swaraj Gurav, Venugopal Kulkarni
}

\begin{abstract}
The efficiency of the 'Injection molding Machine' lies in the proper designing of screw feeder mechanism. The screw feeding mechanism needs to be setup differently for different materials, molds etc. The proper design includes the work from selecting the appropriate materials, designing for the optimum design, analysis of the designed parts at different flow rates, speed and temperatures. There are various parameters that govern the efficiency of the 'Injection molding Machine'. These parameters include 'Filling Pressure', 'Mold Surface Temperature', 'Raw Material Melting Temperature', 'Filling Time' etc.

Keywords: Injection Mounding Machine, Screw Feeder Optimization, Materials Selection, Filling time
\end{abstract}

\section{INTRODUCTION}

Injection Molding Machine are known for their adaptability in manufacturing sector. It can be used for mass production and obtaining highly precise manufactured parts.

Injection molding is a method of manufacturing a plastic product from powdered thermoplastics by supplying the material through hopper to a heated chamber in order to make it easy to mold and force the material into the mold by the using the screw. In this whole process pressure should be persistent till the material is hardened and is ready to be detached from the mold. This is the most common and preferred way of producing a plastic products with any complexity and size.

\section{The injection molding process}

The stages of injection molding process are as follows

1. Polymer is feed through hopper to barrel

2. It is heated to a sufficient temperature to make it flow

3. The molten plastic which got melted will be injected under high pressure into the mold

This process combined is known as Injection. After injection pressure is applied to both plates i.e. fixed and moving plates of the injection molding machine in order to hold the mold tool together afterwards the product is set to cool which helps it in the solidification process.

Revised Manuscript Received on April 25, 2020.

* Correspondence Author

Nimish Joshi*, Pursuing, Stream of mechanical engineering at MIT Academy of Engineering, Pune, India.

Prajakta Hambir, Pursuing, Stream of mechanical engineering at MIT Academy of Engineering, Pune, India.

Pranav Karande, Pursuing, Stream of mechanical engineering at MIT Academy of Engineering, Pune, India.

Swaraj Gurav, Pursuing, Stream of mechanical engineering at MIT Academy of Engineering, Pune, India.

Venugopal Kulkarni, Assistant Professor, MIT Academy of Engineering, Pune

(c) The Authors. Published by Blue Eyes Intelligence Engineering and Sciences Publication (BEIESP). This is an open access article under the CC BY-NC-ND license (http://creativecommons.org/licenses/by-nc-nd/4.0/)
After the product gets its shape the two plates will proceed away from each other in order to detach the mold tool which is known as mold opening and finally the molded product is ejected or removed from the mold. And the process will get repeated.The molding cycle gets started with the recantation of the ejector plate, followed by shutting of the mold. The polymer resin is melted and injected into the mold by the injection unit. Hydraulically operated plunger is used to push the plastic through a heated region. The melt gets converged at a nozzle and is injected into the mold.

The melt is imposed into the mold in two stages:

1. The mold cavities are filled with molten resin. As the material is imposed forward, it gets passed over a spreader (torpedo), within the barrel resulting in mixing. This stage is determined by the rate injection velocity, pressure and time. Injection velocity is defined as the rate at which the plunger gets move forward.

2. Hold stage is started when no more material can be forced into the mold and where melt can still leak back through the gate. Forces are applied against the material in the cavity until the gate freezes to avoid leaking of the melt. In some machines, pack and hold are combined into a single holding stage.

Parts to be injection molded must be very attentively designed to make the molding process smoother; the material used, the desired shape and attributes of the part, the material of the mold, and the properties of the molding machine must all be taken into consideration.Each stage is controlled by a specific pressure and time span. Once the mold is filled and the gate gets cooled, the injection molding machine switches to the cooling stage. The cooling time decides the amount of cooling. After the cycle gets completed and before the next cycle can be run, the machine must be checked and get clearance as per directions in the manual.[7]

\section{Problem statement}

The injection molding machine consists of the hopper, screw, the barrel and the injection nozzle of which the main focus is on the screw feeder of the injection molding machine the aim is to design, optimization and analysis of screw feeder to improve the quality of produces parts and obtain higher production rate. The project focus on increasing the fatigue life of screw feeder and to perform FEA analysis Here our main objectives are to increasing the mass flow rate of the granular plastic resin, thus increasing the machine capcity from 7 shots per min to 11 shots per min, to decrease the weakness in the screw feeder which increases the fatigue life of the screw feeder.

Published By:

Blue Eyes Intelligence Engineering

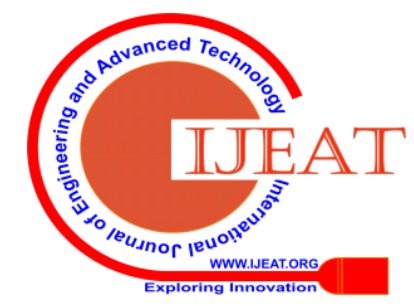




\section{Design and Material Selection of Screw Feeder of Injection Molding Machine}

To reduce the torsional failure of the screw with proper application of coupling. And improving heat convection through barrel. A step of process of designing of any physical object. for the machine is important task for the good optimizations and result. In the context of design, the main goal of material selection is to minimize cost while meeting product performance goals, it allows to design durability and performance of the product.

\section{LITERATURE SURVEY}

The repeatability precision of weight for injection molded products is a major technical parameter to measure the quality and precision of injection molded products and evaluate the performance of injection molding machine. The influence of melt temperature, packing pressure, mold temperature and packing time on the weight of microinjection molding products was studied by Taguchi orthogonal experiment. The influence of peak cavity pressure on the weight of products also got analyzed. The experimental results portrays that the packing pressure is the most major process parameter influencing both the weight of the tensile and the impact specimens.[6]

.Reaction injection molding includes aspects of polymerization reactor analysis as well as melt injection molding. Processing can be broken down into several unit operations: metering and machine performance, impingement mixing, mold filling, curing and mold design. Commercial RIM machines have been used successfully for non-filler systems. The results are generally satisfactory. Reactants are usually allowed to circulate through the mix head, or even through impingement nozzles, such that uniform temperature control and appropriate agitation of reactants can be obtained. Most heads can switch from the recycle to injection mode under high pressure operation, to minimize the lead/lag problem. The mixing chamber is self-cleaned at the end of each shot by a hydraulically driven piston which pushes out all the residue mixture from the mix head after mold filling. Flow rate/flow area can be adjusted externally by the nozzle size adjuster. Flow rate also can be controlled by the pressure setting. Two or four streams impingement mixing is the common mixing technology used in the present RIM machines. Static or impingement type after-mixers have been used extensively to improve the mixing. Mold filling seems not to be a problem for conventional RIM operation if mold design is appropriate. The typical pressure inside the mold cavity during filling is less than $350 \mathrm{KPa}$. With the help of slight foaming during curing, RIM polyurethanes usually have excellent, depression-free surfaces. A number of qualitative descriptions of automotive type RIM have appeared, and some basic studies of the process are being carried out. However, as yet there does not appear to be a complete understanding of how the process influences the structure and properties of the polymer formed. The majority of RIM parts have been made in the 140-300 MPa flexural modulus range for fascia applications, where appearance, weight-reduction, and impact resistance are the most important criteria. A representative formulation used to produce automotive fascia by reaction injection molding consists of a polyether/polyester polyol with molecular weight in the range of 1000-3000, a short chain extender like ethylene glycol, 1,4-butane diol or a diamine and a modified derivative of 1,4-diphenylmethane diisocyanate, MDI. The need for further weight reduction to meet government mileage requirements, and for improved corrosion and impact resistance, makes the extension of RIM materials to other external automotive body components increasingly attractive. For these applications, there will be several new requirements: flexural moduli in the 700-4000 MPa range to provide dimensional stability, but still with the desirable impact strength; a low thermal coefficient of linear expansion to allow satisfactory mating with sheet metal surfaces. An increased thermal stability would also be required for parts that would be painted and baked on the car, or for applications such as hoods with higher in-use thermal exposure.[1]

\section{METHODOLOGY}

\section{A. General Arrangement Layout}

The layout of injection moulding machine was drawn which gave us the overview of the parts and its location in the machine or the system.

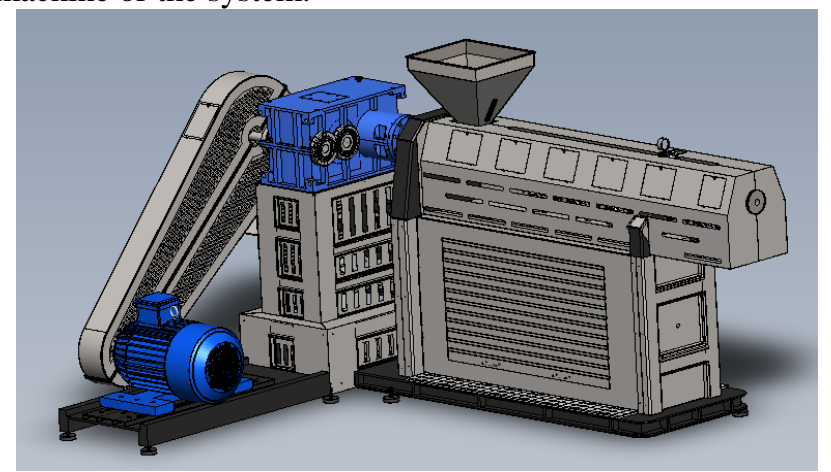

Fig 1:GA layout of Injection Molding Machine

\section{B. Material Selection by Ashby Standard}

It is very crucial process involved in any project. As density and strength were important factors so, for this project we selected density vs strength property chart by Ashby.By using Granta software and importing geometry data to it, we were able to find the candidate material.

Table 1- Candidate material and their properties

\begin{tabular}{|l|l|l|l|}
\hline \multirow{2}{*}{ Material Name } & \multicolumn{3}{|c|}{ Properties } \\
\cline { 2 - 4 } & Yield Strength & Tensile Strength & $\begin{array}{c}\text { Density } \\
(\mathbf{g} / \mathbf{c c})\end{array}$ \\
\hline $\begin{array}{l}\text { Low Carbon steel } \\
8620\end{array}$ & 460 & 455 & 7.20 \\
\hline Carbon Steel 4140 & 700 & 1014 & 4.42 \\
\hline Carbon Steel 135 & 851 & 1100 & 8.40 \\
\hline Stainless Steel 304 & 480 & 510 & 2.73 \\
\hline Stainless Steel 316 & 276 & 310 & 2.70 \\
\hline Tool Steel H13 & 425 & 485 & 2.80 \\
\hline D-2 Tool Steel & 700 & 1029 & 4.68 \\
\hline
\end{tabular}

It is very necessary to identify the function of the element or part for which the material is to be selected. In this case we aim to improve the torsional strength of the part.

Published By:

Blue Eyes Intelligence Engineering

\& Sciences Publication

(C) Convriaht: All riahts reserved.
Retrieval Number: D8928049420/2020@BEIESP

DOI: 10.35940/ijeat.D8928.049420

Journal Website: www.ijeat.org 
There are three methods for quantitative material selection, they are as follows;

1. Cost per Unit Property Method

2. Weighted Properties Method

3. Digital Logic Method

The properties of the materials are scaled based on the weight factor of the physical property which is also known as the weight factor of the property. The scaled property chart is given below,

Table 2:-Candidate Material and Scaled Properties

\begin{tabular}{|l|l|l|l|}
\hline \multirow{2}{*}{ Material Name } & \multicolumn{3}{|c|}{ Scaled Properties } \\
\cline { 2 - 4 } & Yield Strength & Tensile Strength & $\begin{array}{c}\text { Density } \\
\text { (g/cc) }\end{array}$ \\
\hline $\begin{array}{l}\text { Low Carbon steel } \\
\text { 8620 }\end{array}$ & 54.05 & 41.36 & 85.71 \\
\hline Carbon Steel 4140 & 82.256 & 92.18 & 52.60 \\
\hline Carbon Steel 135 & 100 & 100 & 100 \\
\hline Stainless Steel 304 & 56.404 & 46.36 & 32.5 \\
\hline Stainless Steel 316 & 32.432 & 28.18 & 32.142 \\
\hline Tool Steel H13 & 49.941 & 44.090 & 33.33 \\
\hline D-2 Tool Steel & 82.256 & 93.5454 & 55.714 \\
\hline
\end{tabular}

Then, Performance index is calculated for each material. This performance index is then multiplied with the relative cost of that material to get the final material values or say total performance index.

The material with the maximum total performance index is selected as the material for the particular part.

Table 3:-Candidate material and its Relative Cost, Performance Index and Total Performance Index

\begin{tabular}{|l|c|c|c|}
\hline \multicolumn{1}{|c|}{ Material } & Relative Cost & $\begin{array}{l}\text { Performance } \\
\text { Index }\end{array}$ & $\begin{array}{l}\text { Total } \\
\text { Performance } \\
\text { Index }\end{array}$ \\
\hline $\begin{array}{l}\text { Low carbon steel } \\
8620\end{array}$ & 2.9 & 59.319 & 172.027 \\
\hline $\begin{array}{l}\text { Carbon steel } \\
4140\end{array}$ & 6.5 & 76.512 & 497.333 \\
\hline $\begin{array}{l}\text { Carbon steel } \\
135\end{array}$ & 6.1 & 100 & 610 \\
\hline $\begin{array}{l}\text { Stainless steel } \\
304\end{array}$ & 2.1 & 44.25 & 92.930 \\
\hline $\begin{array}{l}\text { Stainless steel } \\
316\end{array}$ & 2.7 & 30.564 & 82.525 \\
\hline $\begin{array}{l}\text { Tool steel } \\
\text { H13 }\end{array}$ & 2.5 & 41.967 & 104.91 \\
\hline $\begin{array}{l}\text { D-2 } \\
\text { Tool steel }\end{array}$ & 8 & 78.112 & 624.901 \\
\hline
\end{tabular}

Through the table plotted above it is clear that the highest calculated performance index is showed by the material D-2 Tool steel and hence this material is finalized for the screw feeder part of the injection moulding machine.

\section{Calculations and Designing}

There are various calculations involved before we actually start making the part. For designing any part these calculations are very important. With the help of calculations we are able to find the dimensions of the part. Other parameters like flow rate, various temperatures, pressure is found out with help of it

Table 4:-Case Studies of parameters

\begin{tabular}{|l|c|c|c|c|}
\hline Description & Case 1 & Case 2 & Case 3 & unit \\
\hline
\end{tabular}

\begin{tabular}{|c|c|c|c|c|}
\hline Description & Case 1 & Case 2 & Case 3 & unit \\
\hline \multicolumn{5}{|c|}{ INPUT } \\
\hline Barrel Diameter & 0.078 & 0.09 & 0.065 & $\mathrm{~m}$ \\
\hline Screw lead & 0.078 & 0.09 & 0.065 & $\mathrm{~m}$ \\
\hline Screw speed & 210 & 190 & 150 & rpm \\
\hline Number of flights & 28 & 35 & 21 & \\
\hline Flight width & 0.005 & 0.003 & 0.004 & $\mathrm{~m}$ \\
\hline Channel width & 0.025 & 0.025 & 0.021 & $\mathrm{~m}$ \\
\hline Depth of the feed zone & 0.007 & 0.005 & 0.004 & $\mathrm{~m}$ \\
\hline Conveying efficiency & 0.25 & 0.25 & 0.25 & \\
\hline Bulk density of polymer & 1000 & 1000 & 1000 & $\mathrm{~kg} / \mathrm{m} 2$ \\
\hline Length of metering zone & 0.201 & 0.16 & 0.014 & $\mathrm{~m}$ \\
\hline Flight clearance & 0.0001 & 0.00013 & $\begin{array}{l}0.0000 \\
5\end{array}$ & $\mathrm{~m}$ \\
\hline $\begin{array}{l}\text { pressure diff. across } \\
\text { metering zone }\end{array}$ & 300 & 300 & 300 & bar \\
\hline Melt viscosity & 1406 & 1406 & 1406 & Pa.s \\
\hline Density of the melt & 1000 & 1000 & 1000 & $\mathrm{~kg} / \mathrm{m} 3$ \\
\hline $\begin{array}{l}\text { Therml conductivity of } \\
\text { the melt }\end{array}$ & 0.174 & 0.174 & 0.174 & $\begin{array}{c}\mathrm{W} /(\mathrm{m} \cdot \mathrm{k} \\
)\end{array}$ \\
\hline $\begin{array}{l}\text { Heat of fusion of the } \\
\text { polymer }\end{array}$ & 125.5 & 125.5 & 125.5 & $\mathrm{KJ} / \mathrm{kg}$ \\
\hline $\begin{array}{l}\text { Specific heat of the solid } \\
\text { polymer }\end{array}$ & 2.2 & 2.2 & 2.2 & $\begin{array}{c}\mathrm{KJ} /(\mathrm{Kg} . \\
\mathrm{k})\end{array}$ \\
\hline Viscosity in the melt film & 1406 & 1406 & 1406 & pa.s \\
\hline Barrel temperature & 140 & 140 & 140 & ${ }^{\circ} \mathrm{C}$ \\
\hline $\begin{array}{l}\text { Meting point of the } \\
\text { polymer }\end{array}$ & 75 & 75 & 75 & $\stackrel{\circ}{C}$ \\
\hline $\begin{array}{l}\text { Temperature of the solid } \\
\text { polymer }\end{array}$ & 40 & 40 & 40 & ${ }^{\circ} \mathrm{C}$ \\
\hline $\begin{array}{l}\text { Density of the solid } \\
\text { polymer }\end{array}$ & 1000 & 1000 & 1000 & $\mathrm{~kg} / \mathrm{m} 3$ \\
\hline Depth of the feed & 0.007 & 0.007 & 0.007 & $\mathrm{~m}$ \\
\hline Empirical Factor & 0.286 & 0.286 & 0.286 & \\
\hline $\begin{array}{l}\text { Melt viscosity in screw } \\
\text { channel }\end{array}$ & 1406 & 1406 & 1406 & pa.s \\
\hline Shear rate in channel & $\begin{array}{l}122.5221 \\
135\end{array}$ & $\begin{array}{l}179.0707 \\
813\end{array}$ & $\begin{array}{l}127.62 \\
72016 \\
\end{array}$ & $\mathrm{~s}-1$ \\
\hline $\begin{array}{l}\text { channel depth at the } \\
\text { outlet }\end{array}$ & 0.003 & 0.003 & 0.003 & $\mathrm{~m}$ \\
\hline $\begin{array}{l}\text { Reciprocal of power } \\
\text { exponent }\end{array}$ & 0.5 & 0.5 & 0.5 & \\
\hline ratio of channel depths & 1 & 1 & 1 & \\
\hline factor & $\begin{array}{l}15562.97 \\
288\end{array}$ & $\begin{array}{l}18814.71 \\
676\end{array}$ & $\begin{array}{l}15883 . \\
89268\end{array}$ & \\
\hline length of the screw zone & 1.68 & 1.24 & 1.1 & $\mathrm{~m}$ \\
\hline Specific heat of melt & 2 & 2 & 2 & $\begin{array}{c}\mathrm{KJ} / \\
(\mathrm{Kg} . \mathrm{k})\end{array}$ \\
\hline The flight diameter & 0.0778 & 0.08974 & 0.0649 & $\mathrm{~m}$ \\
\hline $\begin{array}{lll}\begin{array}{l}\text { vicosity } \\
\text { clearance }\end{array} & & \\
\end{array}$ & 1400 & 1400 & 1400 & pa.s \\
\hline length of the melt zone & 0.201 & 0.201 & 0.201 & \\
\hline Diameter & 0.15 & 0.15 & 0.15 & $\mathrm{~m}$ \\
\hline Torque & 17810 & 14500 & 11200 & $\mathrm{Nm}$ \\
\hline $\begin{array}{l}\text { Accelertion due to } \\
\text { Gravity }\end{array}$ & 9.81 & 9.81 & 9.81 & $\mathrm{~m} 2 / \mathrm{sec}$ \\
\hline
\end{tabular}




\section{Design and Material Selection of Screw Feeder of Injection Molding Machine}

\begin{tabular}{|c|c|c|c|c|}
\hline Description & Case 1 & Case 2 & Case 3 & unit \\
\hline Desity of the screw metal & 7850 & 7850 & 7850 & $\mathrm{~kJ} / \mathrm{m} 3$ \\
\hline Elastic modulus of screw & $2.1 \mathrm{E}+11$ & $1.9 \mathrm{E}+11$ & $2 \mathrm{E}+11$ & $\mathrm{~Pa}$ \\
\hline Allowable shear stress & $\begin{array}{l}1.00 \mathrm{E}+0 \\
8\end{array}$ & $\begin{array}{l}1.00 \mathrm{E}+0 \\
8\end{array}$ & $\begin{array}{l}1.00 \mathrm{E}+ \\
08\end{array}$ & MPa \\
\hline $\begin{array}{lr}\text { non-uniform } & \text { pressure } \\
\text { diff. around } & \text { screw } \\
\text { circumference } & \\
\end{array}$ & 3000000 & 3000000 & $\begin{array}{l}300000 \\
0\end{array}$ & $\mathrm{~Pa}$ \\
\hline \multicolumn{5}{|c|}{ OUTPUT } \\
\hline Helix angle & $\begin{array}{c}0.308169 \\
071 \\
\end{array}$ & $\begin{array}{c}0.308169 \\
071 \\
\end{array}$ & $\begin{array}{l}0.3081 \\
69071\end{array}$ & rad \\
\hline $\begin{array}{l}\text { Conveying rate in feed } \\
\text { zone } \\
\end{array}$ & $\begin{array}{c}290.2793 \\
748 \\
\end{array}$ & $\begin{array}{c}277.6477 \\
489 \\
\end{array}$ & $\begin{array}{l}85.506 \\
84199\end{array}$ & kg/hr \\
\hline $\begin{array}{c}\text { Volume flow rate of } \\
\text { pressure flow }\end{array}$ & $\begin{array}{c}0.000054 \\
37266\end{array}$ & $\begin{array}{c}0.000006 \\
02243\end{array}$ & $\begin{array}{c}0.0000 \\
446371 \\
4\end{array}$ & $\mathrm{~m} 3 / \mathrm{s}$ \\
\hline mass flow rate & $\begin{array}{c}195.7415 \\
736\end{array}$ & $\begin{array}{c}21.68076 \\
552\end{array}$ & $\begin{array}{c}160.69 \\
37044\end{array}$ & $\mathrm{~kg} / \mathrm{h}$ \\
\hline Drag flow & $\begin{array}{c}0.000168 \\
989\end{array}$ & $\begin{array}{c}3.04868 \mathrm{E} \\
-05\end{array}$ & $\begin{array}{l}1.7614 \\
6 \mathrm{E}-05\end{array}$ & $\mathrm{~m} 3 / \mathrm{s}$ \\
\hline mass flow rate & $\begin{array}{c}608.3601 \\
545 \\
\end{array}$ & $\begin{array}{c}109.7525 \\
219 \\
\end{array}$ & $\begin{array}{c}63.412 \\
56822 \\
\end{array}$ & $\mathrm{~kg} / \mathrm{h}$ \\
\hline $\begin{array}{c}\text { ratio of pressure flow to } \\
\text { drag flow }\end{array}$ & $\begin{array}{c}0.321752 \\
784 \\
\end{array}$ & $\begin{array}{c}0.197542 \\
299 \\
\end{array}$ & $\begin{array}{c}2.5340 \\
98664\end{array}$ & \\
\hline Melt conveying rate & $\begin{array}{c}0.000403 \\
928 \\
\end{array}$ & $\begin{array}{c}8.52182 \mathrm{E} \\
-05 \\
\end{array}$ & $\begin{array}{c}9.8073 \\
8 \mathrm{E}-05\end{array}$ & \\
\hline Average shear rate & $\begin{array}{c}122.5221 \\
135\end{array}$ & $\begin{array}{c}179.0707 \\
813\end{array}$ & $\begin{array}{l}127.62 \\
72016\end{array}$ & \\
\hline $\begin{array}{l}\text { Velocity of the barrel } \\
\text { surface }\end{array}$ & $\begin{array}{c}0.857654 \\
794 \\
\end{array}$ & $\begin{array}{c}0.895353 \\
906 \\
\end{array}$ & $\begin{array}{l}0.5105 \\
08806\end{array}$ & $\mathrm{~m} / \mathrm{sec}$ \\
\hline Velocity of the solid bed & $\begin{array}{c}0.460760 \\
912 \\
\end{array}$ & $\begin{array}{c}0.440710 \\
713\end{array}$ & $\begin{array}{l}0.1615 \\
77555\end{array}$ & $\mathrm{~m} / \mathrm{sec}$ \\
\hline Relative velocity & $\begin{array}{c}0.441313 \\
52 \\
\end{array}$ & $\begin{array}{c}0.493840 \\
553 \\
\end{array}$ & $\begin{array}{c}0.3598 \\
95591 \\
\end{array}$ & $\mathrm{~m} / \mathrm{sec}$ \\
\hline Velocity component & $\begin{array}{c}0.260139 \\
11\end{array}$ & $\begin{array}{c}0.271573 \\
796\end{array}$ & $\begin{array}{c}0.1548 \\
44709\end{array}$ & $\mathrm{~m} / \mathrm{sec}$ \\
\hline Thickness of melt film & $\begin{array}{c}0.000103 \\
673 \\
\end{array}$ & $\begin{array}{c}0.000101 \\
482 \\
\end{array}$ & $\begin{array}{l}0.0001 \\
23132 \\
\end{array}$ & $\mathrm{~m}$ \\
\hline $\begin{array}{l}\text { Average film } \\
\text { tempterature }\end{array}$ & 107.5 & 107.5 & 107.5 & ${ }^{\circ} \mathrm{C}$ \\
\hline Temperature of melt film & $\begin{array}{c}238.6442 \\
617 \\
\end{array}$ & $\begin{array}{c}271.7208 \\
617 \\
\end{array}$ & $\begin{array}{l}194.71 \\
83525\end{array}$ & ${ }^{\circ} \mathrm{C}$ \\
\hline Melt pressure & $\begin{array}{c}403.9740 \\
008 \\
\end{array}$ & $\begin{array}{c}389.2400 \\
0 \\
\end{array}$ & $\begin{array}{c}390.24 \\
000\end{array}$ & bar \\
\hline Thermal diffusivity & $\begin{array}{c}0.000000 \\
087 \\
\end{array}$ & $\begin{array}{c}0.000000 \\
087 \\
\end{array}$ & $\begin{array}{l}0.0000 \\
00087\end{array}$ & $\mathrm{~m} 2 / \mathrm{s}$ \\
\hline The parameter $\beta$ & $\begin{array}{c}0.100574 \\
713 \\
\end{array}$ & $\begin{array}{c}0.153783 \\
525 \\
\end{array}$ & $\begin{array}{c}0.0179 \\
5977\end{array}$ & \\
\hline $\begin{array}{l}\text { Heat transfer btw melt } \\
\text { and barrel }\end{array}$ & $\begin{array}{c}788.5189 \\
83\end{array}$ & $\begin{array}{c}890.2427 \\
621\end{array}$ & $\begin{array}{c}543.80 \\
56235\end{array}$ & $\begin{array}{c}\mathrm{W} /(\mathrm{m} 2 . \\
\mathrm{k})\end{array}$ \\
\hline $\begin{array}{c}\text { Correction factor for } \\
\text { screw power }\end{array}$ & $\begin{array}{c}1.007177 \\
812 \\
\end{array}$ & $\begin{array}{c}1.003402 \\
758 \\
\end{array}$ & $\begin{array}{l}1.0029 \\
14867\end{array}$ & \\
\hline $\begin{array}{c}\text { Power dissipated in } \\
\text { screw channel }\end{array}$ & $\begin{array}{c}61.21308 \\
44 \\
\end{array}$ & $\begin{array}{c}63.93375 \\
179 \\
\end{array}$ & $\begin{array}{l}27.300 \\
85278\end{array}$ & KW \\
\hline $\begin{array}{c}\text { Power dissipated in flight } \\
\text { clearance }\end{array}$ & $\begin{array}{c}9.505041 \\
688 \\
\end{array}$ & $\begin{array}{c}5.972463 \\
247 \\
\end{array}$ & $\begin{array}{l}4.0495 \\
74567\end{array}$ & KW \\
\hline $\begin{array}{c}\text { power required to raise } \\
\text { pressure of melt }\end{array}$ & $\begin{array}{c}1.631179 \\
78\end{array}$ & $\begin{array}{c}0.180673 \\
046\end{array}$ & $\begin{array}{l}1.3391 \\
14203\end{array}$ & KW \\
\hline Screw power & $\begin{array}{c}72.34930 \\
587 \\
\end{array}$ & $\begin{array}{c}70.08688 \\
809 \\
\end{array}$ & $\begin{array}{c}32.689 \\
54155\end{array}$ & KW \\
\hline Max Shear Stress & $\begin{array}{c}2687572 \\
8.94\end{array}$ & $\begin{array}{c}2188085 \\
7.36\end{array}$ & $\begin{array}{c}169010 \\
76.03\end{array}$ & $\mathrm{~Pa}$ \\
\hline Max Feed depth & $2.66 \mathrm{E}-02$ & 2.98E-02 & $\begin{array}{c}\text { 3.35E- } \\
02\end{array}$ & $\mathrm{~m}$ \\
\hline $\begin{array}{l}\text { Lateral deflection of } \\
\text { screw }\end{array}$ & $\begin{array}{c}0.000259 \\
659\end{array}$ & $\begin{array}{c}0.000286 \\
992\end{array}$ & $\begin{array}{l}0.0002 \\
72642\end{array}$ & $\mathrm{~m}$ \\
\hline $\begin{array}{c}\text { Critical Pressure for } \\
\text { buckling }\end{array}$ & $\begin{array}{c}2581.683 \\
629 \\
\end{array}$ & $\begin{array}{c}2335.808 \\
998 \\
\end{array}$ & $\begin{array}{l}2458.7 \\
46313\end{array}$ & bar \\
\hline $\begin{array}{c}\text { Critical Screw Speed for } \\
\text { vibraions }\end{array}$ & $\begin{array}{c}14513.81 \\
012 \\
\end{array}$ & $\begin{array}{c}13805.38 \\
715 \\
\end{array}$ & $\begin{array}{l}14164 . \\
02836 \\
\end{array}$ & RPM \\
\hline Horizontal force & 756000 & 756000 & 756000 & $\mathrm{~N}$ \\
\hline
\end{tabular}

With help of 3D CAD software such Solid works the Screw feeder was designed on the basis of basic dimensions to be analysed for further investigation.

\section{D.Analysis}

There are various types of analysis carried out on a part. For the Screw feeder we used Finite Element analysis. It reduces the cost of actual prototyping and testing. Number of tests are carried out with help of soft wares to optimize the product and develop it faster.

The software we used for the analysis of the screw feeder is solid works. The parameter applied was torsional force. The result was obtained in the form of stress, strain, displacement and factor of safety.

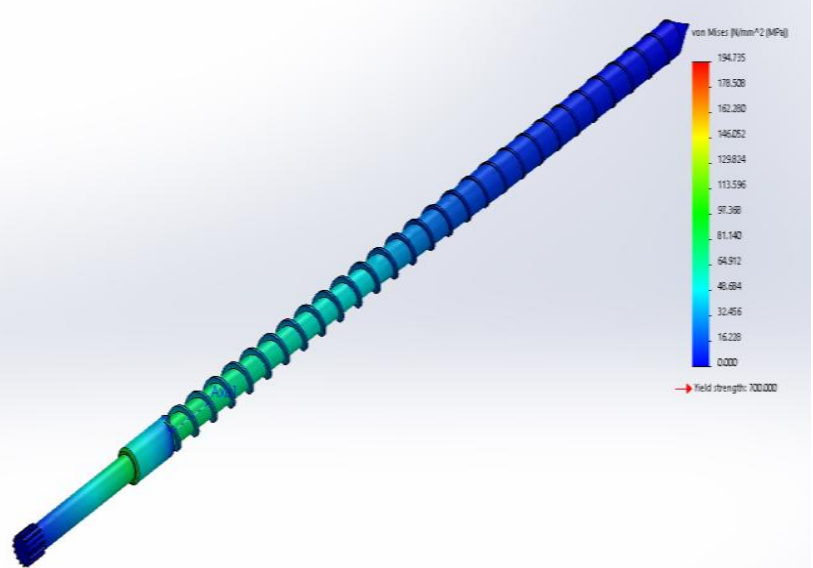

Fig 2: Analysis of the screw feeder for the von misses stress.

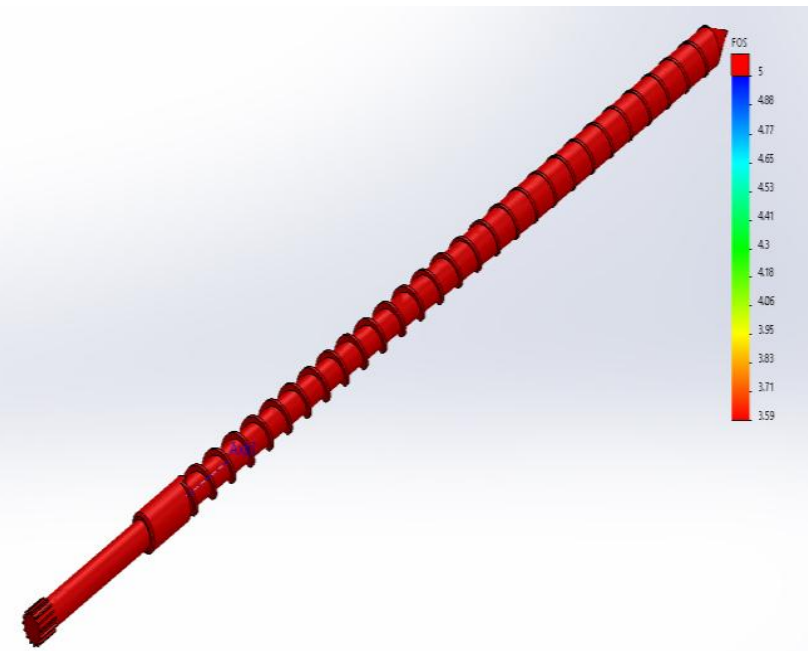

Fig 3: Analysis of the screw feeder for the factor of safety

\section{RESULTS}

The material D2 tool steel and carbon steel 135 showed good results through the software. Both the materials showed high torsional strength. However the displacement were same for both the materials.

Table 5:-Candidate Material and its FOS and Yield Strength

\begin{tabular}{|l|l|c|}
\hline Material & FOS & Yield strength \\
\hline Low carbon steel 8620 & 2.4 & $460 \mathrm{MPa}$ \\
\hline Carbon steel 135 & 4.4 & $850 \mathrm{MPa}$ \\
\hline Carbon Steel 4140 & 3.6 & $700 \mathrm{MPa}$ \\
\hline
\end{tabular}




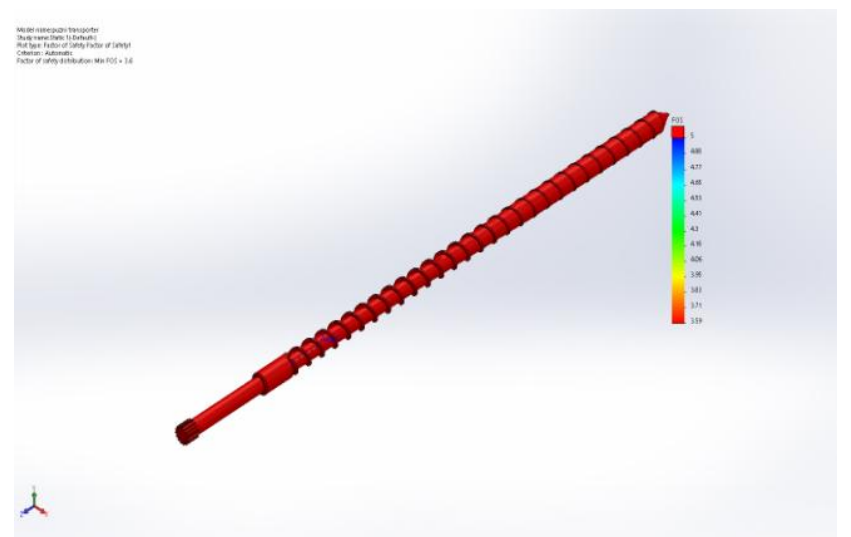

Fig 4:-Analysis of Screw Feeder for D2 Steel(FOS=3.6)

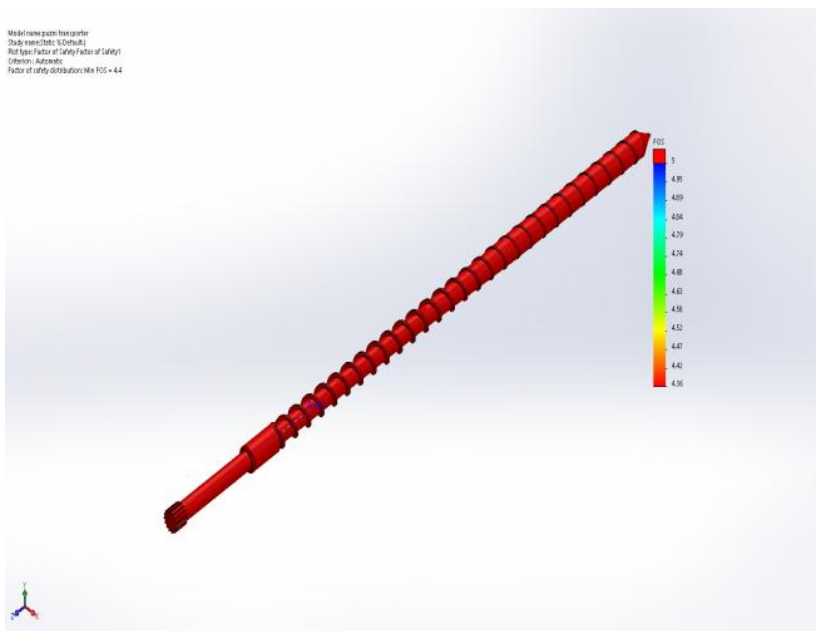

Fig 5:-Analysis of screw feeder for Carbon Steel 135(FOS=4.4)

\section{CONCLUSION}

The initial design of the screw feeder of the injection moulding was studied and based on that it was redesigned with respect to dimensions and material to gain a control over the output. The capacity of the injection moulding was optimised taking the inputs and constraints into consideration. The analysis was performed on the designed screw feeder to check or verify its functioning under working conditions. It was found out that D-2 Tool steel as a material would be best to select for the screw feeder. The calculations and analysis were successfully completed.

\section{REFERENCES}

1. .L. J. Lee 'Polyurethane Reaction Injection Molding: Process, Materials, and Properties' (Rubber Chemistry and Technology, July 1980,Vol. 53,No.3,Page no. 542-599)

2. Spiros Zinelisa; Olga Annousakia; Margarita Makoub; Theodore Eliadesa 'Metallurgical Characterization of Orthodontic Brackets Produced by Metal Injection Molding (MIM)' (The Angle Orthodontist,2005,Page no. 1024-1031)

3. Mangels, J.A. 'Low-pressure injection molding' (American Ceramic Society Bulletin;Vol 73:5;April 1994)

4. R A Siregar,S F Khan,K Umurani 'Design and development of injection moulding machine for manufacturing maboratory'(Journal of physics, Volume 908,August 2017,Page no. 21-22)

5. Gurjeet Singh,Ajay Verma 'A Brief Review on Injection Moulding Manufacturing Process' (Materials Today,Vol. 4(2),December 2017,Page no. 1423-1433)
6. Quan Wang,Jinrong Wang,Chongying Yamg,Kaihui Du,Wenli Zhu,Xiaoli Zhang 'Effect of Process parameters on repeatability precision of Weight foe Microinjection Molding Prducts(Advances in Polymer Technology Vol.2019(6),June 2019,Page no. 1-8)

7. Samson Teklehaimanot 'Simulation and Design of a plastic injection Mold’ (Degree Thesis,PTE,2011)

\section{AUTHORS PROFILE}

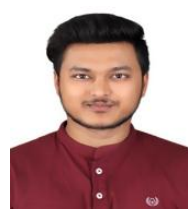

Nimish Joshi is a co-author to this research paper. He is pursuing his graduation in the stream of mechanical engineering at MIT Academy of Engineering, Alandi, India. He has jointly published research paper on 'Automatic Weighing and Packaging Machine'.He is good at developing solutions through arduino projects.

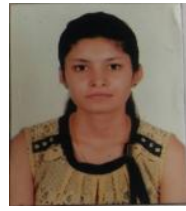

Prajakta Hambir is a Undergraduate research student of MIT Academy of Engineering, Pune and she is pursuing degree in Mechanical Engineering. She has done research work on effect of compression ratio on performance of diesel engine.She has also jointly published research paper on 'Automatic Weighing and Packaging Machine'.

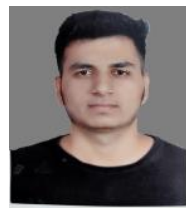

Pranav Karande is an undergraduate research scholar and co-author to this research paper. He is pursuing his graduation in the stream of mechanical engineering at MIT Academy of Engineering, Alandi, India. He has done research work in developing microcontroller based smart helmet kit. He has jointly published research paper on 'Automatic Weighing and Packaging Machine'.

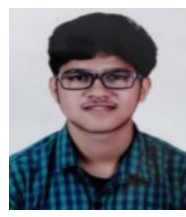

Swaraj Gurav is an undergraduate research scholar and co-author to this research paper. He is pursuing his graduation in the stream of mechanical engineering at MIT Academy of Engineering, Pune, India.He has worked on developing an agriculture automation bot and has also worked on research base analysis of Electrocalescenes by using non uniform electric field.

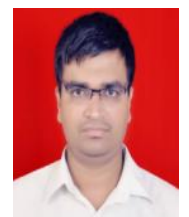

Venugopal Kulkarni Working as Assistant Professor in MIT Academy of Engineering, Pune from June 2016 Associated with Institution of Mechanical Engineers (IMechE), UK since December 2016. Working as Industrial consultant in Chakan, Pune Industrial area for activities like training, quality since 2016. Working industrial experience of around more than four years and teaching experience of more than six years.

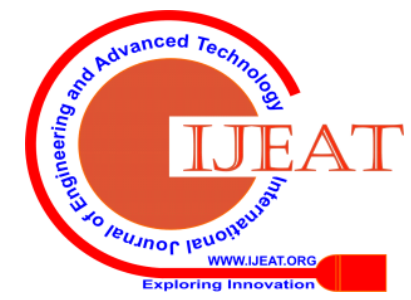

